For citation: Chernova E. G. \& Razmanova S. V. (2018). Development of Competitive Environment at the Oil Market of Russian Federation: Empirical Analysis. Ekonomika regiona [Economy of Region], 14(2), 547-561

doi 10.17059/2018-2-17

UDC 339.9

JEL L42, L44, L7 1

E. G. Chernova ${ }^{\text {a) }}$, S. V. Razmanova ${ }^{\text {b) }}$

a) Saint Petersburg State University (Saint-Petersburg, Russian Federation)

b) Branch Office of LLC Gazprom VNIIGAZ in Ukhta (Ukhta, Russian Federation; e-mail: s.razmanova@sng.vniigaz.gazprom.ru)

\title{
DEVELOPMENT OF COMPETITIVE ENVIRONMENT IN THE OIL MARKET OF RUSSIAN FEDERATION: EMPIRICAL ANALYSIS
}

The purpose of this research is the assessment of the competitive environment in the Russian oil market. The subject-matter of the study is the Russian oil and gas companies as a basis of the Energy market. We check the hypothesis about the development of the mechanism of corrective condition in the sphere of preliminary control of market concentrations in the fuel and energy complex (FEC). The basis of this research is the modern theory of industry markets studying various structures of the markets, the behavior of their participants, probable consequences of their functioning and interaction, as well as the impact of the state on the functioning of markets, its participants, and the results of their activities. We calculated and analyzed the key indicators characterizing the processes of market concentration in the oil industry. We also considered the competition policy of the Russian Federation in mergers and acquisitions deals (M\&A deals) concerning oil and gas assets. The authors estimated over 460 decisions made by the Federal Antimonopoly Service of the Russian Federation for the period from 2011 to 2015 in the control on economic concentration in fuel-and-energy industry. Based on the data characterizing the development of competitive environment, we have proved that the considered goods market belongs to markets with insufficiently developed competition. The results of the research will make a certain contribution to studying the efficiency of M\&A transactions in the oil and gas industry, and also can be applied for the implementation of anti-monopoly actions by the Federal Antimonopoly Service of the Russian Federation.

Keywords: oil companies, gas companies, mergers, acquisitions, index of concentration of the first $\mathrm{n}$ firms, Herfindahl-Hirschman index, antimonopoly policy, behavioral instructions, structural instructions

\section{Introduction}

The competitive environment in the Russian Federation began to form in the conditions of the refusal of the methods of the planned economy by business entities. Reforms of the last decade of the XX centuries proclaimed the transition to market economy. However, new institutes and processes were reproduced for quite a long time. It constrained the development of the market relations, determining both the state and business actions up to the beginning of the 2000th. Among the main features of business in the period of the transitional economy of the Russian Federation, it is possible to note its criminal nature (including raiding), legal nihilism, the drive to the market power and abnormal profit for short terms, injurious resource consumption.

The companies' incentives for the formation of the production and managerial innovations necessary for the creation of comparative competitive

\footnotetext{
${ }^{1}$ (c) Chernova E. G., Razmanova S. V. Text. 2018.
}

advantages were at a low level at that time. The existing scheme of redistribution of the main financial resources through the government budget and control over prices of products and services of natural monopolies distorted the functioning of a market mechanism.

The report of Audit Chamber gives expert evaluations concerning the results of privatization ${ }^{2}$, it says that in Russia «there is the highest level of concentration of private property in the world. That is there is a situation which slows down the processes of achievement of competitiveness of the Russian economy. The small and average owners and entrepreneurs, being in the developed democratic states a driving force of economic de-

\footnotetext{
2 Analiz protsessov privatizatsii gosudarstvennoy sobstvennosti v Rossiyskoy Federatsii za period 1993-2003 gody [The analysis of privatization processes of state-owned property in the Russian Federation for the period 1993-2003]. (2004). Moscow: Olita Publ. Retrieved from:http://nationalization.ru/ Library/aHAJIu3_C4eTHOu_nAJIATbIdf.pdf (date of access: 06.07.2017).
} 
velopment and support of political stability, have not taken place in Russia».

Privatization and a considerable degree of production concentration in many respects explain the processes of mergers and acquisitions in the Oil and Gas industry taking place in the second half of the 1990th, and the beginning of the 2000th years. The change of owners during the post-privatization period can be connected with processes of transition of corporate control. Such transition was, as a rule, in the form of sale of packets of voting shares between the groups of persons whose affiliation was not evident for the external observer, owing to the lack of proper transparency of the vast majority of the companies. At the same time, in the current conditions, the change of an owner of a company as a result of integration processes can be connected to the structural changes and the growth of its efficiency.

As a rule, the competitive situation is considered by the analysis of the various types of market structures, from the point of view of the size of business or in an industry view. In foreign and domestic scientific works studying of theoretical and applied aspects of competition policy and anti-monopoly regulation, the development of the ideas of its structure and tools is provided by Bain J.S., Sherer F.M. and Ross D.; Sheferd A. and Sheferd D.; Duso T., Gugler K., Szücs F.; Nocke V., Whinston M.; Thomasin S.; Mason R., Weeds H.; Breinlich H., Schutz N.; Avdasheva S.B.; Rozanova E.A.; Pakhomova N.V. and Richter K.K.; Kapelyushnikova R.I.; Draft E.G.; Quickly I.P.; Shastitko A.E., etc. [1-10]. In the analysis of competitive situation, researchers focus on the intensity of the competition and the nature of its development, operating with the following parameters: barriers on an entrance/exit for/from the market, the concentration level of factors influencing the offer (a cost structure, geographical, product boundaries of the market) and demand (elasticity of demand, product quality, its differentiation), transparency and efficiency of the competitive legislation [11-13]. Information on concentration in the certain industrial markets is generalized by the means of calculation and analysis of a number of indices of concentration. Among the indices, it should be noted an index of concentration of the first n firms; Herfindahl-Hirschman (HHI) index; Gini coefficient; index of entropy; and Lerner's index.

In the scientific literature, there are various approaches to the analysis of competitive or market environment, market structures and competitive processes. This perspective is studied in detail within the economy of the industrial markets with an allocation of the key determining parameters mentioned-above. And it partly finds the application in current domestic anti-monopoly regulation when implementing the competition policy. At the same time, there is a deficit of applied researchers on a number of separate key industries. For example, the modern national oil industry is the oligopolistic market. There have been the active processes of concentration for the last decades. Can this industry be in a competitive line? Can we talk about the effective regulation of oil industry, especially concerning the tendency of transition under the State control?

During this research, we check the hypothesis of the development of the mechanism in the sphere of preliminary control of market concentration deals preliminary control in the fuel and energy complex (FEC).

The authors designated the existing barriers to enter to the market of crude oil, and also productive and geographical boundaries of the market. In this research, we considered some aspects of Russian competition policy, anti-monopoly regulation, and control of market concentration.

\section{Research Methodology}

Methodological basis of the research is the current theory of industrial markets. Within the theory, the main factors determining the market structure are the following: a number of producers, their concentration ratio, distribution of market shares, extent of vertical integration within the value chain; economic indications of products (quality, extent of differentiation, proximity to substitutes); cost structure of companies (economies of scale, network benefits, subadditivity); barriers of an entrance and an exit from the market, the extra expenses; security with information; concentration and market power of buyers; the conditions determining the sales demand (trends, cyclic and seasonal fluctuations).

Market concentration is a measure of intensity either the competition or a control indicator over the market. Its market share can serve as the measuring instrument of the size of a company. The following indices for determining the market concentration are the most known: index of concentration of the first $n$ firms (CRn) and Herfindahl-Hirschman index (HHI). Also, for the mergers deals must use the data of the Federal Antimonopoly Service of the Russian Federation concerning Oil and Gas companies assets.

The majority of researchers [14, pp. 596619 ; 15, pp. 1200-1251; 16, pp. 1201-1251; 17, pp. 1003-1033; 18, pp. 391-401; 19, pp. 11141144 ; 20, pp. 1019-1041; 21, pp. 277-319] ana- 
lyze the efficiency of competitiveness at the industrial markets from the point of view of the policy of antimonopoly authorities concerning to horizontal mergers, correction of the offered mergers or prohibition of non-competitive mergers. Furthermore, they analyse the factors able to break decisions in the field of merger control»one-way» effects in horizontal mergers, especially in the differentiated goods markets. In some papers [22, pp. 23-38; 23], there is analyzed the optimization policy of antimonopoly authority, which is out of control for maximizing the expected consumer profit, oblige more tough standards on large merges, where take part firms, which occupied a big share of the market before the merge.

\section{Assessment of the Competitive Environment in the Oil Market}

The main Federal law in the Russian Federation concerning the maintenance and development of the competition is the Federal law of 26.07.2006 No. 135-FZ «About the competition protection». Before accepted this law, since 1991, various versions of the RSFSR Law were accepted (22.03.1991 No. 948-1 «About the competition and restriction on monopolistic activities concerning products markets"; and since 1999, the Federal law of 23.06.1999 No. 117-FZ «About the protection of competition on the market of financial services»).

According to the Competition Law of the Russian Federation, it is forbidden the market abuse (for example, in the form of establishment of monopoly prices, tying the contract conditions or the restriction for the access to the market), including the holders of natural monopoly. It is also forbidden to make anti-competitive agreements engage in concerted action). For the authorities, it is forbidden to provide privileges and benefits to certain companies. Competitive requirements for the tenders and auction at the implementation of state procurements are established; the unfair competition is forbidden.

Statistics of M\&A confirms the dynamics of the concentration processes in the Russian economy. The data of reports of the KPMG company for 2012 demonstrate that in case of a small number of M\&A deals in an oil-and-gas sector (10,7 percent from their total quantity in 2012) cost value is $50,5 \%$ of a total cost of M\&A in the Russian economy. ${ }^{1}$ Following the results of 2015 , the abovestated sizes are 8,7 and $27,9 \%$ respectively. Such

\footnotetext{
1 The market of M\&A in Russia in 2012. (2013). Moscow: KPMG. Retrieved from: https://www.kpmg.com/RU/ru/ Issues AndInsights/ArticlesPublications/Documents/S_ MA_2r\%202013.pdf (date of access: 17.07.2016). (In Russ.)
}

statistics, emphasizing the activity of the concentration processes in the oil sector, also pay attention to the high cost of oil and gas assets concerning the total assets of the Russian companies. Activity in the market of M\&A in 2015 significantly decreased till 504 transactions (against 623 transactions in 2014).

However, problems with liquidity led to the reduction in the number of large deals (over 2 billion US dollars), which historically were a factor for the growth of the Russian M\&A market. Thus in 2015, only four mergers of such scale were announced (in 2013 - 14). At the same time, in a segment of small mergers, the activity has increased: the number of merges for less than 100 million US dollars increased by 1,8 times till 185 transactions (in 2013 - 104 transactions). ${ }^{2}$

Data on the dynamics of oil extraction by the Russian companies during the period from 2004

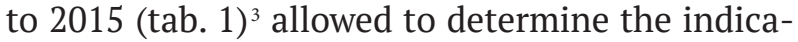
tors of a market share (S) and a square of market share (S2) used further when calculating the market concentration index.

We have considered mainly the market of crude oil, so, it should be noted that sellers in the researched market are the oil companies to carry out oil extraction, and buyers - the companies

2 Russian M\&A review 2015. (2016). Moscow: KPMG, 32. Retrieved from: https:/assets.kpmg.com/content/dam/kpmg/ pdf/2016/03/ru-en-russian-ma-review-2015.pdf (date of access: 15.11.2016).

${ }^{3}$ Oil extraction of Russian companies (2005). Energy industry of Russia: Results of productive activity of industries for 2004. Moscow: 1. 3-7. (In Russ.); Oil extraction of Russian companies. (2006). Energy industry of Russia: Results of productive activity of industries in December and since the beginning of 2005. Moscow, 1, 2-8. (In Russ.); Oil extraction of Russian companies (2007). MINTOP: Results of productive activity of industries of energy industry in December and since the beginning of 2006. Moscow: 1. 22-27. (In Russ.); Oil extraction of Russian companies (2008). MINTOP: Results of productive activity of industries of energy industry in January-December, 2007. Moscow, 1. 22-27. (In Russ.); Oil extraction of Russian companies. (2009). MINTOP: Results of productive activity of industries of energy industry for 2008. Moscow, 1, 22-27 (In Russ.).; Oil extraction of Russian companies (2010). MINTOP: Results of productive activity of industries of energy industry for January-December, 2009. Moscow, 1. 22-29.; Oil-and-gas and oil-processing industry (2011). Energy industry of Russia. Moscow, 1. 2-7. (In Russ.); Oil-and-gas and oil-processing industry (2012). Energy industry of Russia. Moscow, 1, 2-7. (In Russ.); Oil-and-gas and oil-processing industry (2013). Energy industry of Russia. Moscow, 2, 2-7. (In Russ.); Oil-and-gas and oil-processing industry. Energy industry of Russia, 2, 2-7. (In Russ.); Oil and gas extraction in December, 2014 (2015). Oil and the equity. Moscow: Oil and Equity publishing House, 2, 56-59. (In Russ.); Oil and gas extraction in November-December, 2015 (2016). Oil and the equity. Moscow: Oil and Equity publishing House, 1-2, 57-64. (In Russ.) 
$\frac{0}{\frac{0}{\pi}}$

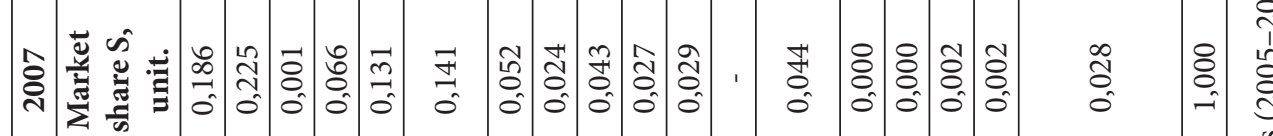

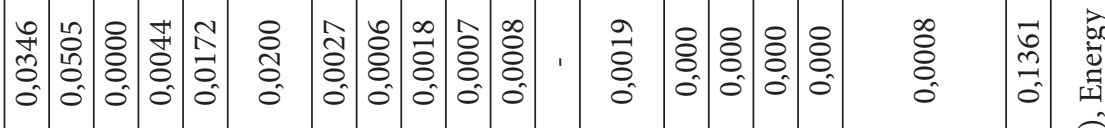

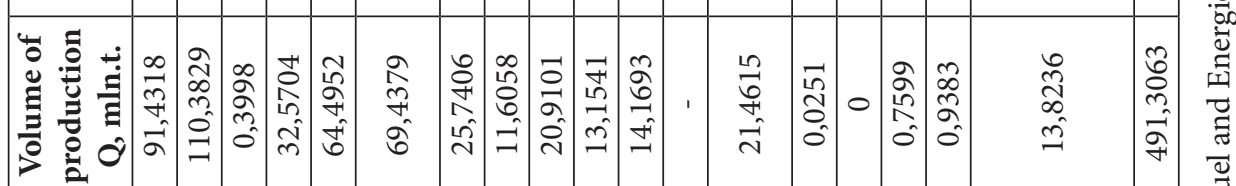

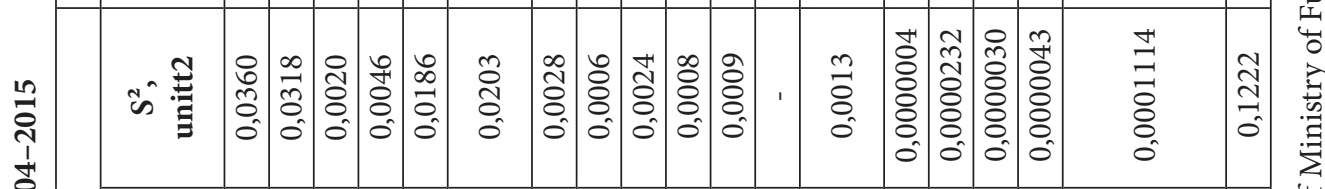

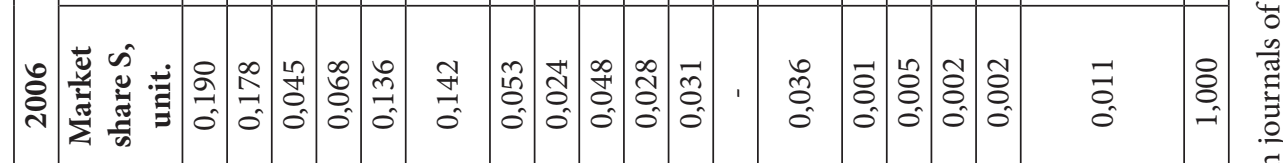

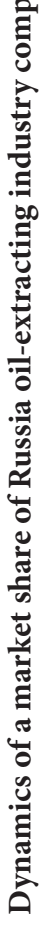

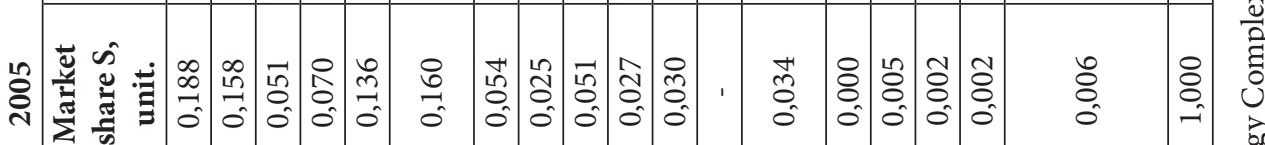
要

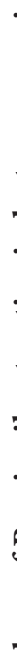

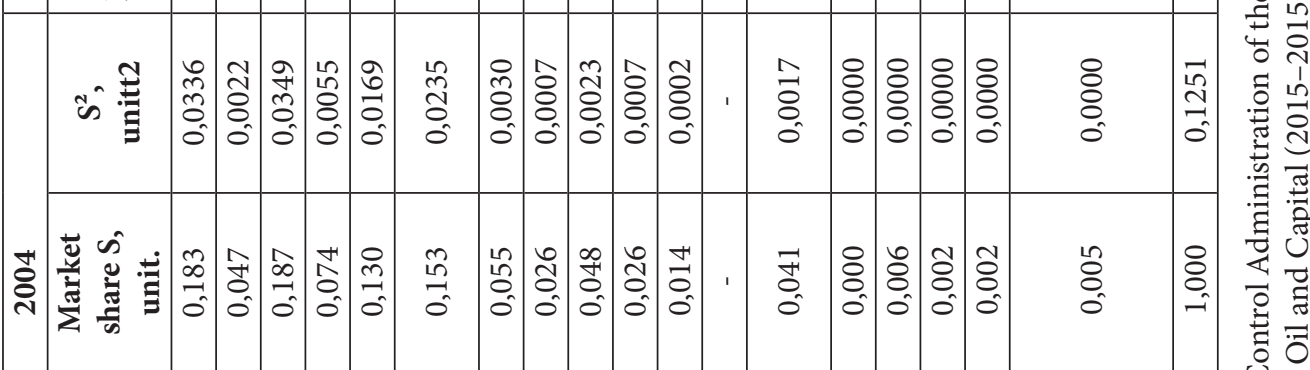

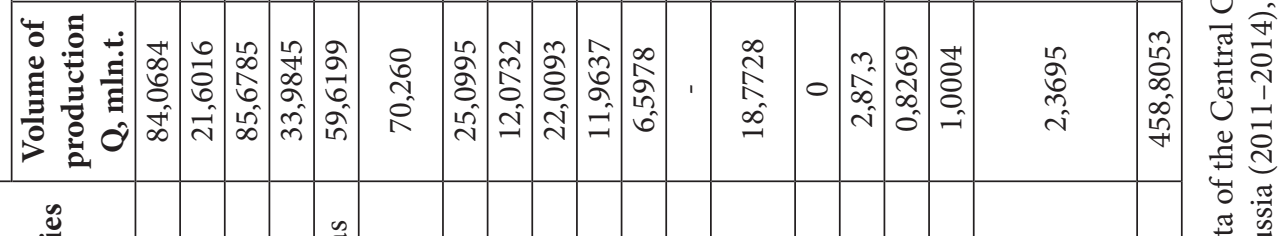

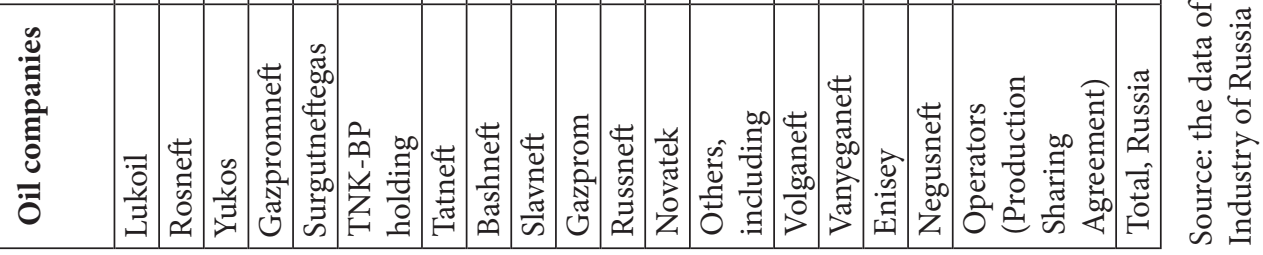


]

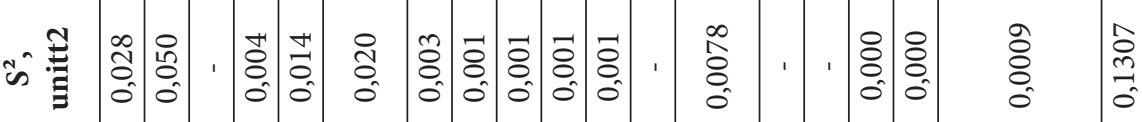

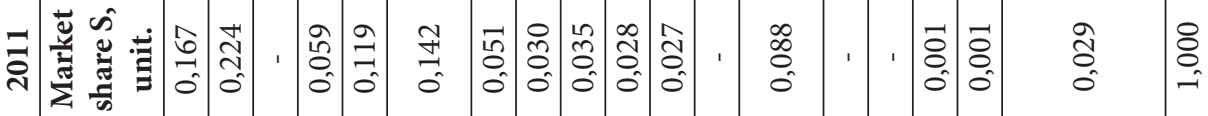

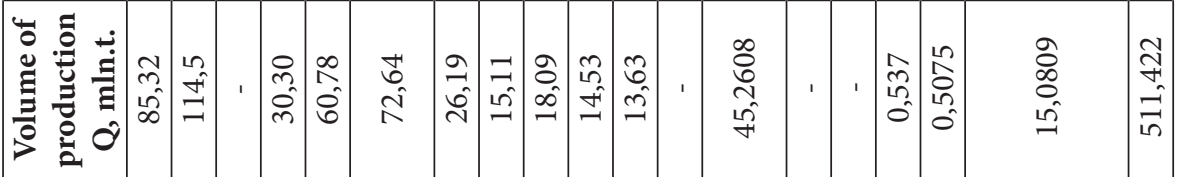

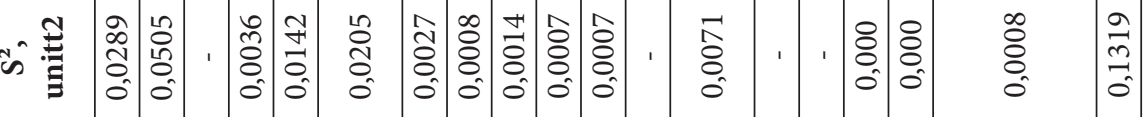

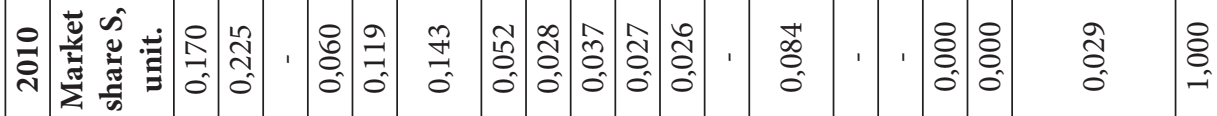

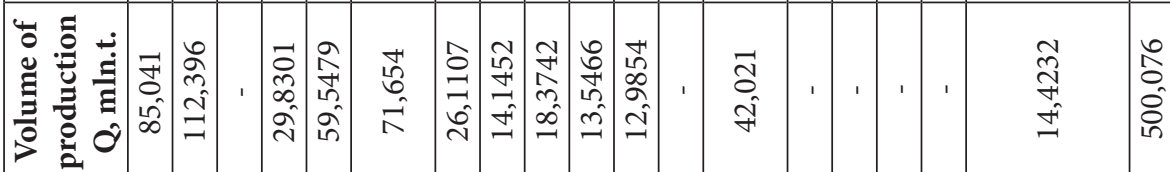

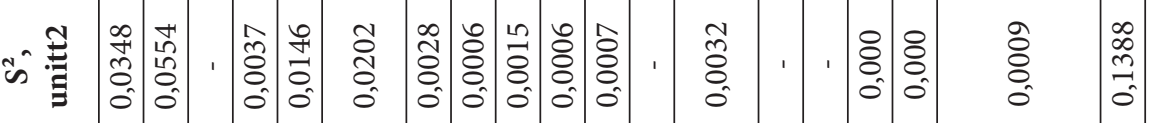

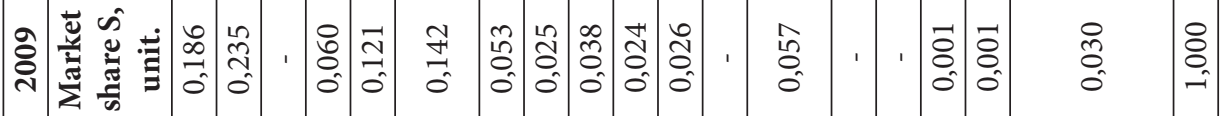

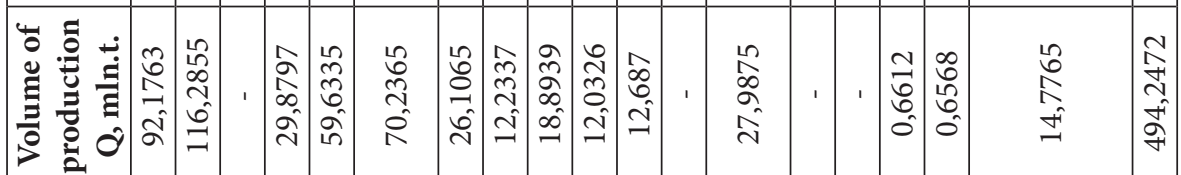

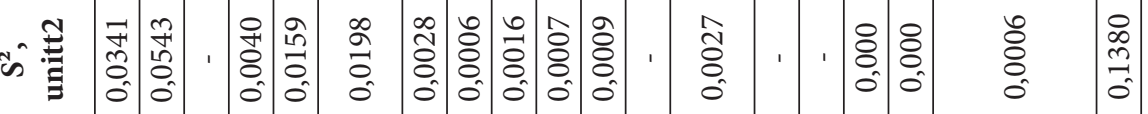

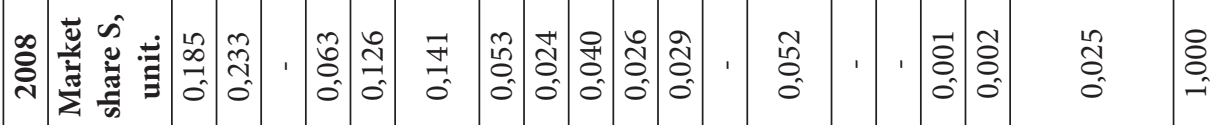

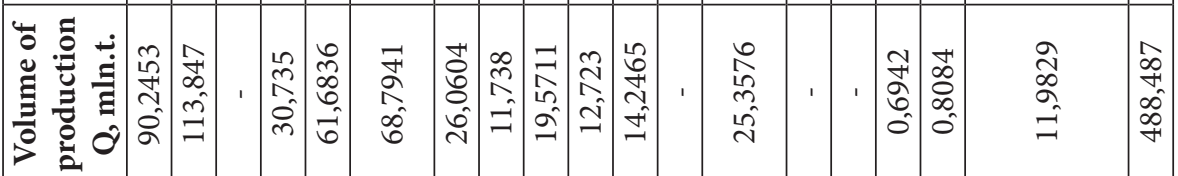

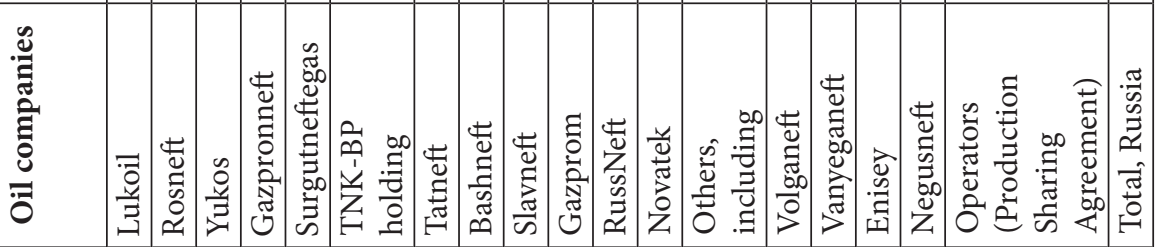


害

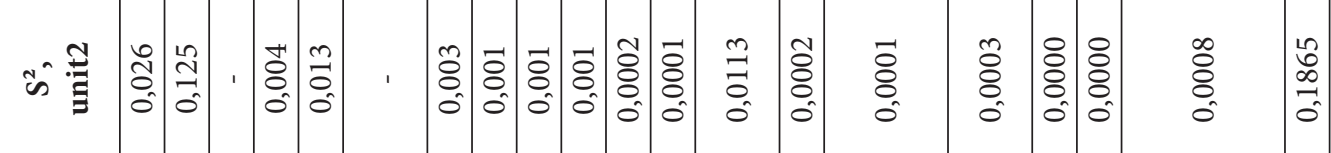

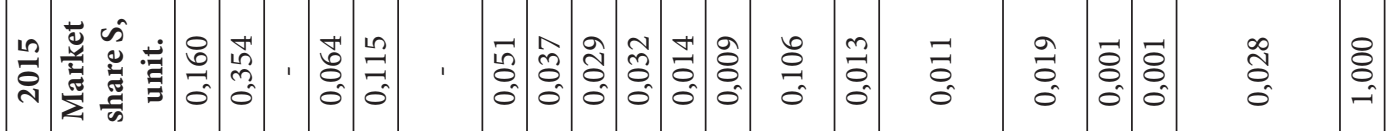

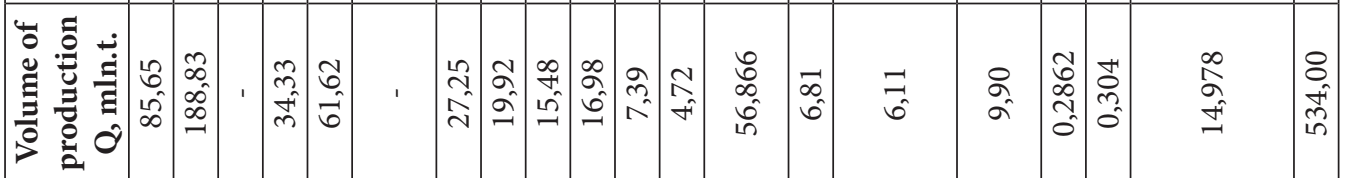

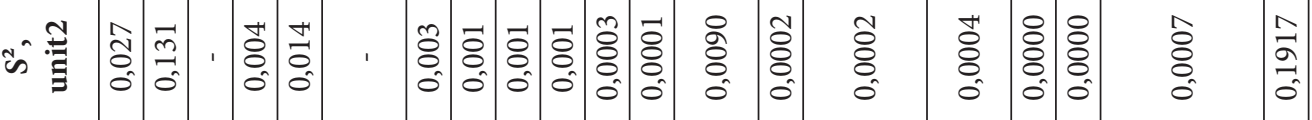

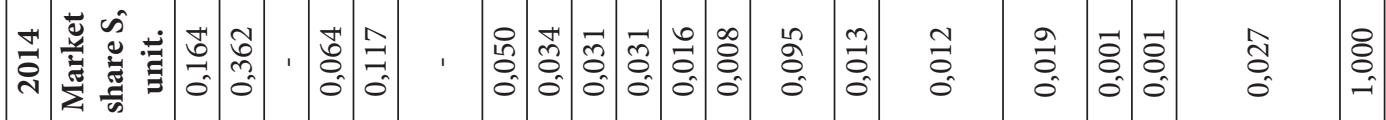

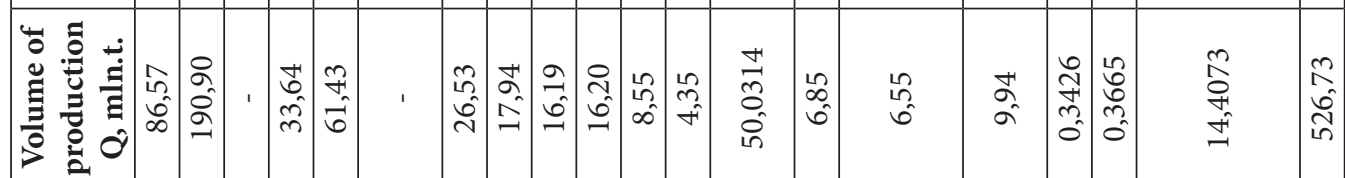

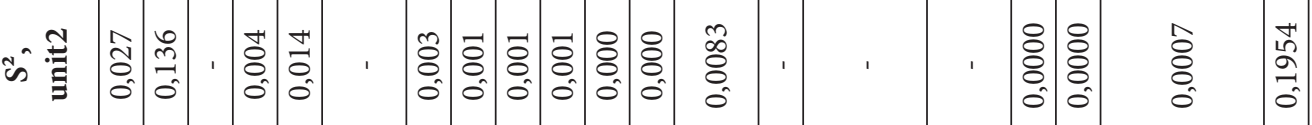

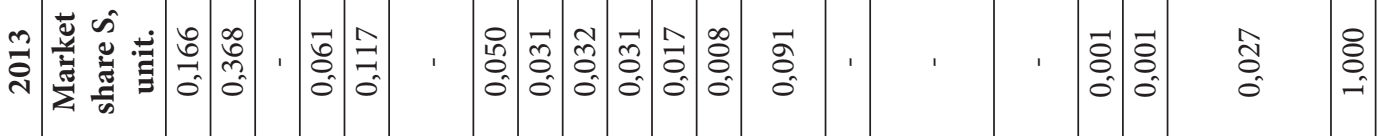

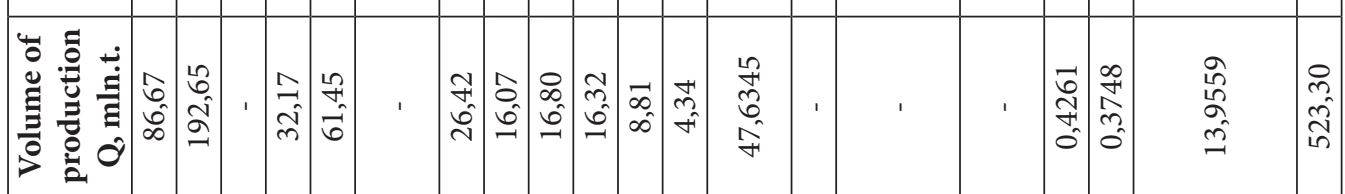

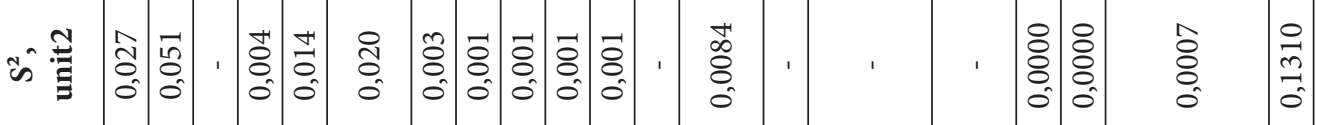

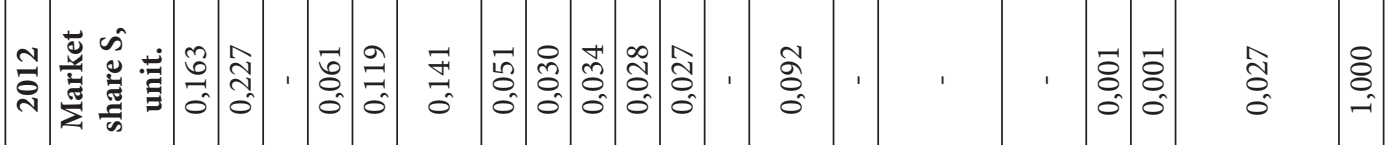

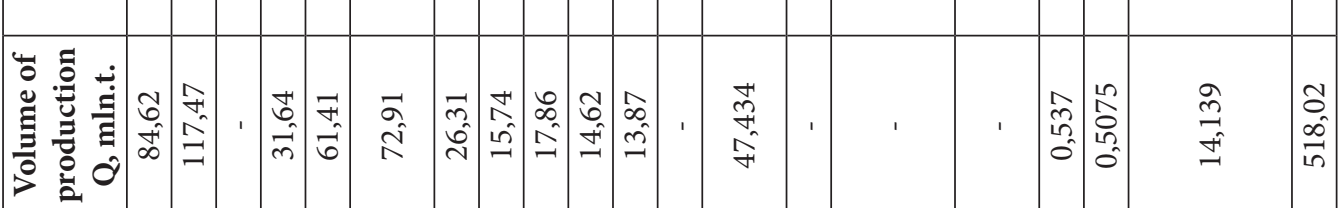

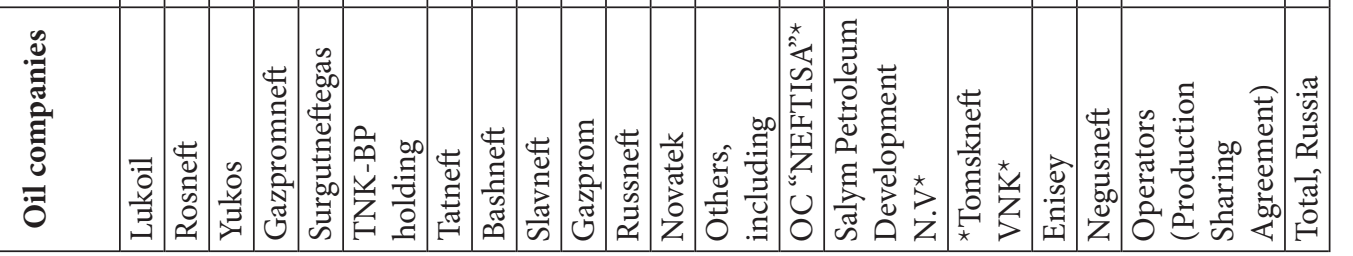


The calculated value of the index of concentration of the first $\mathbf{n}$ firms in oil sector

\begin{tabular}{|l|c|c|c|c|c|c|c|c|c|c|c|c|}
\hline \multirow{2}{*}{ Name of index } & \multicolumn{10}{|c|}{ Value of an indicator, unit } \\
\cline { 2 - 33 } & $\mathbf{2 0 0 4}$ & $\mathbf{2 0 0 5}$ & $\mathbf{2 0 0 6}$ & $\mathbf{2 0 0 7}$ & $\mathbf{2 0 0 8}$ & $\mathbf{2 0 0 9}$ & $\mathbf{2 0 1 0}$ & $\mathbf{2 0 1 1}$ & $\mathbf{2 0 1 2}$ & $\mathbf{2 0 1 3}$ & $\mathbf{2 0 1 4}$ & $\mathbf{2 0 1 5}$ \\
\hline$C R_{4}$ & 0,653 & 0,642 & 0,646 & 0,683 & 0,685 & 0,684 & 0,657 & 0,652 & 0,649 & 0,713 & 0,707 & 0.694 \\
\hline$C R_{8}$ & 0,877 & 0,868 & 0,861 & 0,873 & 0,870 & 0,861 & 0,834 & 0,827 & 0,826 & 0,857 & 0,853 & 0.843 \\
\hline
\end{tabular}

Source: it is calculated on the data of tab. 1.

purchasing crude oil for resale or performing its conversion (the petrochemical and oil processing companies).

The structure of the Russian oil sector express oligopolistic nature and is characterized by the vertically integrated oil companies (VIOC), which carry out activities on all segments of the market: production and oil refining, storage, wholesale, small wholesale and retail sale of oil products.

For the characteristic of the concentration of the oil market, we must address indices of the concentration of the first $n$ firms $\left(C R_{n}\right)$ and HHI. We should note that the concentration is a measure of the intensity of the competition or an indicator of control over the market. Its market share can serve as the measuring instrument of the relative size of a company.

For the Russian oil industry (tab. 2), the calculated value of indices of the concentration of the first 4 firms $\left(C R_{4}\right)$ did not exceed $80 \%$. It says about the average degree of concentration of the market.

It should be noted that the market shares of the oil companies Lukoil, Yukos, Surgutneftegas and TNK - BP participated in the calculation of the $C R_{4}$ index in 2004. The $C R_{8}$ index for 2004 also included the oil companies Rosneft, Sibneft (subsequently Gazpromneft), Tatneft and Slavneft. Since 2005, the Yukos and Rosneft companies made the redistribution. As a result, Rosneft has become one of four leading Russian Oil companies. The Yukos company in terms of production was among the first eight companies of the industry, but since 2007 finally closed. The Russneft company participated in the calculation of the $C R_{8}$ index in 2007 -2009. Since 2010, Bashneft was among first 8 oil companies instead of Russneft. After the transfer of assets of TNK-BP to JSC Rosneft, according to the results of production in 2013-2015, Rosneft, Lukoil, Surgutneftegas and Gazpromneft companies are included in the $C R_{4}$ index. The $C R_{8}$ index is added with the Tatneft, Bashneft, Slavneft and Gazprom companies.

During the period from 2004 to 2015, for the Oil industry, the HHI value increased from 1251 up to 1865 , whereas the number of equivalence decreased from 8,0 to 5,4 units (fig. 1 and fig. 2). That demonstrates that concentration degree in an oil sector approached critical value 2000 behind which it should be considered as the market with the high level of concentration.

At the same time, according to the Federal Antimonopoly Service (FAS) of the Russian Federation in 2013, the value of the $\mathrm{HHI}$ and $C R_{4}$ indices made 2001,9 units and 77,6\%, respectively ${ }^{1}$. According to the results of 2013, FAS characterizes the market of crude oil as a high-concentrated one.

It is considered, that industries with the highest coefficients of concentration also have the highest rates of the level of production of innovative products.

At the same time, the share of technological innovations at the companies relating to the sphere of energy production did not changed much. For example, in 2006, the level of technological innovations in energy sector constituted $8,0 \%$, in 2012 and 2014 were $8,3 \%$ and 7,4 \%, respectively. ${ }^{2}$ The average value of an intensity of technological costs, marketing, and organizational innovations in the mining industry for the organizations more than 10000 people constituted $2,0 \%$ that corresponds to the level of the industry, which has an average technological level. ${ }^{3}$ However, if to address the ratio of the costs for the Research and Development to oil and gas companies revenue, this ratio will hardly exceed $0,9 \%$. Thus, the increase in the level of merger control deals of the oil sector practically does not imply the innovative activities of these companies. It can be explained by the fact that nature of interrelation between the competition and innovation very strongly depends on the institutional

\footnotetext{
${ }^{1}$ The analytical report on competitive situation analysis results in the market of crude oil for 2013. (2013). Moscow: Federal antimonopoly service. Retrieved from: http://www.fas.gov.ru/analytical-materials/analytical-materials_31102.html (date of access: 17.07.2016). (In Russ.)

${ }^{2}$ Indicators of innovative activities: 2009: / Statistical collection / N.V. Gorodnikova, L. M. Gokhberg, K. A. Ditkovsky, etc. M.: Higher School of Economics National Research University. - 2009. - 488 pages; Indicators of innovative activities: 2016: / Statistical collection / N. V. Gorodnikova, L. M. Gokhberg, K.A. Ditkovsky, etc. - M.: Higher School of Economics National Research University. - 2016. - 320 pages.

${ }^{3}$ Ibid, p. 77.
} 


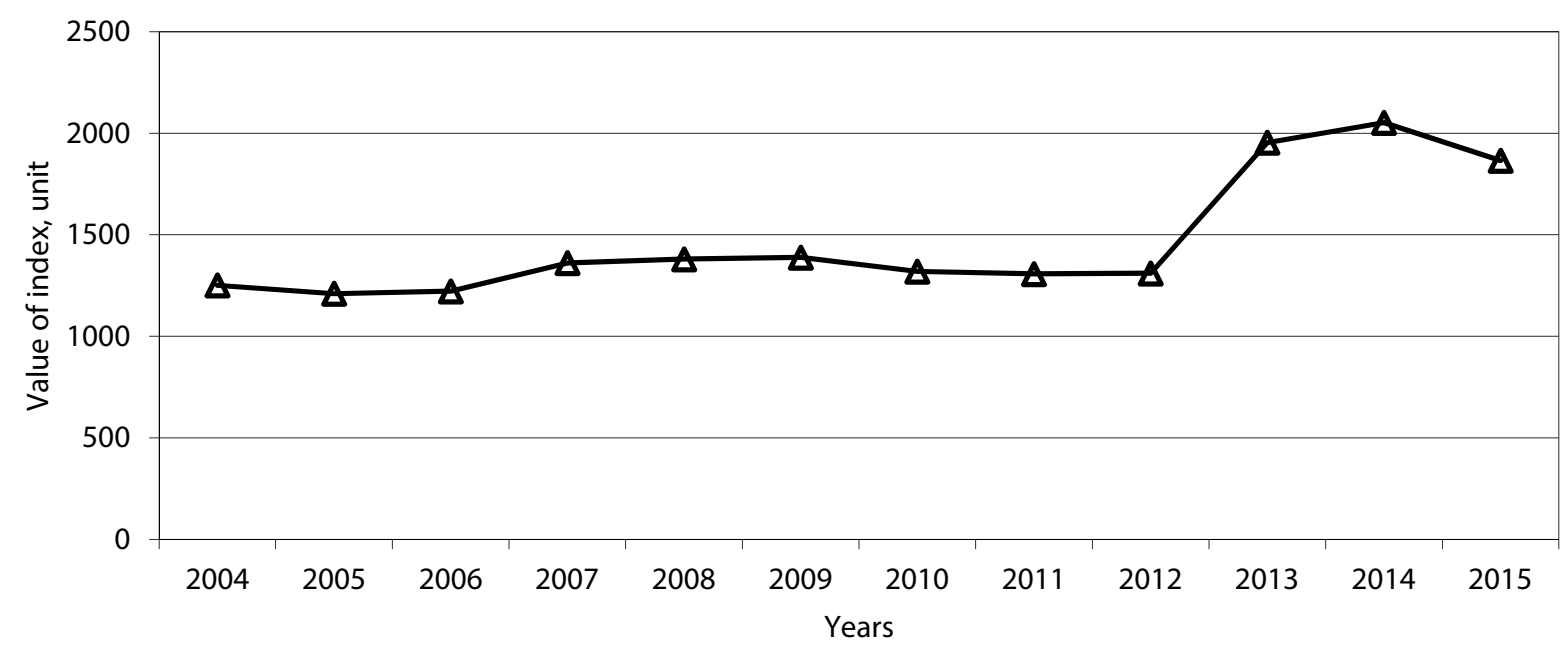

Source: it is calculated on tab. 1

Fig. 1. Dynamics of HHI in the Oil sector in 2004-2015

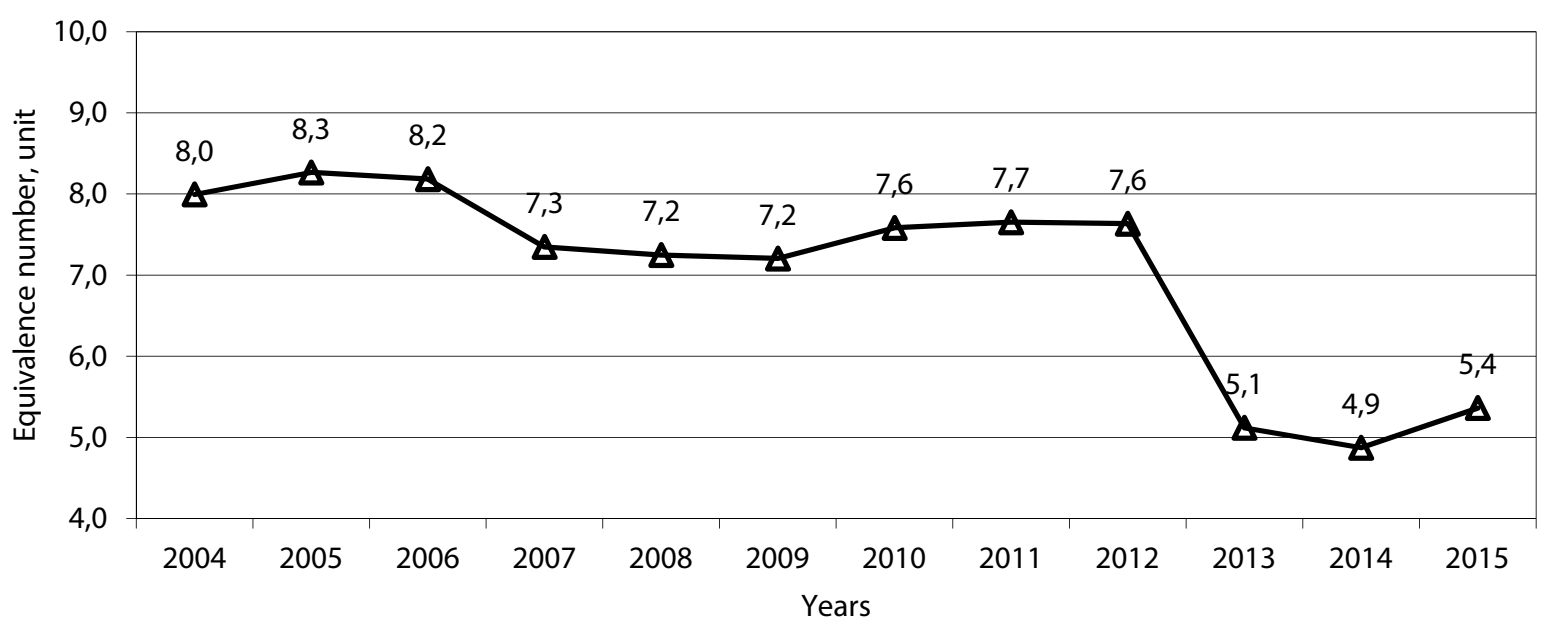

Source: it is calculated on the data of tab. 1

Fig. 2. Dynamics of the number of equivalence in the oil sector in 2004-2015

features of the Russian economy, as well as the structure of the oil and gas market.

During 2004-2015, there is the tendency of the further growth of economic concentration among the largest companies of the industry, as well as the increase of the State companies in the oil markets. It is also necessary to note that the reduction of the extracted oil by independent mining companies concerning their integration into the structure of Vertically Integrated Oil Company stopped near 2000th.

In the report of $\mathrm{FAS}^{1}$, it is noted that from 1998 to 2007 the amount of production of small oil enterprises decreased twice - from $10 \%$ of total amount to $5 \%$. Indeed, if to consider the market share of the independent companies (tab. 2), then, for example, in 2004 it constituted only $4,1 \%$, and

\footnotetext{
${ }^{1}$ The report on a competitive situation in the Russian Federation. (2008). Moscow: Federal antimonopoly service. Retrieved from: http://fas.gov.ru/about/list-of-reports/list-of-reports_9.html (date of access: 17.07.2016).
}

in $2005-3,4 \%$ that represents the minimum value over the last ten years. Since 2006, the market share of independent oil producers has been increasing. In 2007 and 2008 resulted 4,4\% and $5,2 \%$, respectively. As the results of 2015 , the amount of production of small oil enterprises made $10,6 \%$ (the same as in 1998) despite all mergers and acquisitions happening in the oil industry in the last 15 years.

The existing level of economic concentration and the vertical integration cause the main barriers to the entrance and implementation of profitable activities in the markets of crude oil and oil products.

The governmental restrictions to enter the oil market are the following: the need to obtain licenses, environmental constraints, the need to achieve results at the hard geological and weather conditions, the use of innovative technologies access to which is limited. 
Another barrier to entry the market are the limited number of refining facilities and limited capacity to use pipeline service of JSC Transneft system, as well as the existence of Vertically Integrated Oil Companies, which possess more than $70 \%$ of capacities on processing of crude oil. ${ }^{1}$

Vertically Integrated Oil Companies (VINK) dominate at the market of crude oil and downstream operation: following the results of 2015, more than 69,37 \% of oil in the Russian Federation are extracted by four large VINK (Rosneft, Lukoil, Surgutneftegas, Gazprom Neft). More than 68,0 \% of the Russian oil is processed at the plants controlled by this VINK. ${ }^{2}$ Each of the designated VINK holds a dominant position in the market of crude oil and, besides, has an additional opportunity to make an essential impact on the main conditions of the buy-sell of goods in the oil market. The sizes of shares of other vertically integrated oil companies during the long period (for a year) are subject to insignificant changes. Access to the market of crude oil in the Russian Federation for new competitors is complicated. Thus, the comparison and analysis of the quantitative and qualitative indices characterizing the market of crude oil allows to draw the following conclusion: the Russia oil market belongs to the market with insufficiently developed competition.

As a result of the monitoring of the conditions of wholesale and retail oil markets and the level of oil price made by FAS and by its territorial authorities in 2007-2015, the violations have been revealed from a number of VINK (Gazprom Neft, TNK-BP Holding, Rosneft and Lukoil). They were expressed in the establishment of exclusively high prices of oil products; creation of discrimination conditions for buyers; establishment of unreasonable prices for oil products through economical and technologic conditions.

All decisions and instructions of FAS formed the basis of three «waves» of violation cases of the antitrust law by the largest vertically integrated oil companies. Following the results of a socalled third wave by the Resolution of Presidium of the Supreme Arbitration Court of the Russian Federation, it was established that geographical boundaries of the goods market of oil products are the territory of the Russian Federation. It was also recognized the corporate domination of

\footnotetext{
${ }^{1}$ The analytical report on competitive situation analysis results in the market of crude oil for 2013. (2013). Moscow: Federal antimonopoly service. Retrieved from: http://www.fas.gov.ru/analytical-materials/analytical-materials_31102.html (date of access: 17.07.2016). (In Russ.)

${ }^{2}$ The market for oil products and natural gas in Russia. Results of 2015. (2016). Moscow: Algorithm Publ., 16. (In Russ).
}

Rosneft, Lukoil, Gazprom Neft and TNK-BP companies. Also, it was determined that product borders of the wholesale markets of oil products are automobile types of gasoline, diesel fuel, and aviation kerosene because of these goods cannot be replaced in the case of consumption. ${ }^{3}$

Nowadays, in the wholesale market, a consumer (an independent trader) does not purchase at an inflated price light oil products at nearby oil refinery. He purchases goods at distant oil refineries but at the effective price. From all oil refineries, fuel oil and diesel fuel are also exported to the overwhelming number of regions of the country. Thus, transportation expenses are not a restraining factor for deliveries to the market. In the national oil wholesale market, the change of the consumption conditions in one place leads to a change of cargo flows in the market, in general. Similarly in the world markets: the change of sales terms in one of the leading centers of trade (ARA, MED or SING) leads to the change of the general terms of sales. Fuel from the Russian Federation is exported at the world prices, which impact on the Russia domestic market taking into account protective measures. ${ }^{4}$

Besides, FAS has also carried out monitoring of three basic indices of market prices: stock exchange quotations on oil and the main oil products, curb prices on oil and the main oil products, the comparable prices of the foreign markets.

It should be noted that the oil world pricing system, both in exchange and off-exchange segments, is constructed on the price indices published by the PLATTS and ARGUS, agencies which acquired long statistics regarding dynamics of the price. World trade in oil products, derivatives, a system of the taxation, etc. is built on this data. However, these price indices are created by the private companies' own methods. There are no procedures for internal and external control guaranteeing their justification, selection of data on deals is not representative one.

Nowadays, the practice of the Russian Federation is much better than before. According to the trade results of 2015, on the Russian exchange platform of CJSC St. Petersburg International Commodity Exchange, more than 15,9 million tons of oil products were sold. If the world agen-

\footnotetext{
${ }^{3}$ Golomolzin, A. N. (2013). Anti-monopoly regulation of energy industry: 2010-2012: Presentation. (2013). Moscow: Federal antimonopoly service. Retrived from: http://chel.fas. gov.ru/analytic/6644 (date of access: 07.2016). (In Russ.)

${ }^{4}$ Some results of activities of FAS of 2004-2012: Report. (2013). Moscow: Federal antimonopoly service. Retrieved from: http:// fas.gov.ru/about/list-of-reports/list-of-reports_30067.html (date of access: 17.07.2016). (In Russ.)
} 
cies use own procedures of selective «reporting» transaction prices, then in Russia, the procedure of registration of total actual transactions by an amount more than 119 million tons is applied. That is in 10 times bigger, than the world agencies use. Exchange auction corresponds to the rules of the antitrust law and to the legislation on the organized auctions. The registration of transactions is obligatory according to the Russia Government Acts and the code of the Russian Federation about administrative violations. Thus, Russian estimates are more reasonable, representative and reliable these days.

Undertaken measures allowed to create in the Russian Federation the commercial infrastructure of the market of oil and oil products, stock exchange trading by an available good is under development, and also it is recorded OTC (over the counter deal) at the Stock Market. Thereby, we have obtained the right information about the market of oil products. Now, in the Russian Federation OTC in Rubbles for oil products begin to be concluded. Addition activities on forming the basic conditions for the creation of the Russian price indicators on benchmark crude are held.

\section{Competition Policy of the Russian Federation in M\&A of Oil and Gas Assets}

Regulation of M\&A deals in the Russian Federation is based on the Federal law of 26.07.2006 No. 135-FZ «About protection the competition «. Management of transactions implies the control of economic concentration in the Russia market, which is controlled by the Federal Antimonopoly Service of the Russian Federation.

During 2004-2012, at the initiative of the Federal Antimonopoly Service of the Russian Federation, the antitrust legislation was upgraded. It significantly improved quality of the legislation valid from 1991; to unify the Russian antitrust law with the best samples of the European and American antitrust law; to remove excess barriers to business; to give to antimonopoly authority additional powers to against monopolim in the market and noncompetitive actions of authorities for the purpose of enhancement of law-enforcement practice. «The first antimonopoly packet» of laws was accepted in 2006 and unified two earlier acting laws «About the Competition and Restriction of Monopolistic Activities in the Goods Markets» and «About Protection of the Competition in the Market of Financial Services». ${ }^{1}$

\footnotetext{
${ }^{1}$ Some results of activities of FAS of 2004-2012: Report. (2013). Moscow: Federal antimonopoly service. Retrieved from: http:// fas.gov.ru/about/list-of-reports/list-of-reports_30067.html (date of access: 17.07.2015). (In Russ.)
}

In 2009, «the second antimonopoly packet» of laws came into force and specified a conceptual framework (in particular, determination of «the monopoly price of goods»); strengthened control for anti-competitive actions of authorities'; updated the principles for control of market concentration (for example, there is appeared the requirement about disclosure of the final beneficiary); increased threshold values of the organizations assets. With the change of the 178th article of the Criminal Code of the Russian Federation, there is appeared the real criminal sanction for an antitrust violation (up to 7 years of imprisonment).

The «Third anti-monopoly packet» of laws, which came into force in January 2012 carried specifying and in many respects liberal nature. In particular, it specified requirements to anti-competitive agreements and coordinated actions; specified an order on the provision of the stateowned and municipal property; fixed an administrative order of appeal of trading results; entered the mechanism of "warning" of antitrust violations; determined the circumstances of mitigating and aggravating responsibility, etc.

As a preventive measure, some M\&A deals can be carried out after agreement of antimonopoly authorities. The changes in the area of the state control of economic integration connected with acceptance of «the first and second antimonopoly laws packet» can be seen in Table 3 .

Reforms in field of control of market concentratioin occurred not only in Russia. In the European Union, for example, the consideration of M\&A deals are made according to the EU Directions or mergers (last change of Directives was in 2004). The monitoring authority making decisions on market concentration is the management of European Commission on competition issues.

Foreign researchers [14, pp. 596-619] estimated over 350 company M\&A deals approved by the European Commission and the main legislative reform entered in 2004, having covered the period of $1990-2007$. Results of their research show that because of the supervision of mergers and characteristics of companies, it is possible to unmistakably predict the results of about $70 \%$ of mergers. Legislation reform of 2004 increased this percent to $76 \%$. But researchers note that in spite of the fact that legislation reform of 2004 increased "policy predictability and reduced the quantity of mistakes», in the EU, there are still many opportunities to prevent the noncompetitive mergers able harm the consumer.»

Within the control on market concentration, Federal Antimonopoly Service of the Russian Federation makes the following decisions: 
Change of administrative barriers in the field of State control on economic integration during 2004-2015*

\begin{tabular}{|c|c|}
\hline Before modernization of antitrust legislation & After modernization of antitrust law legislation \\
\hline $\begin{array}{l}\text { Threshold values for preliminary coordination of merg- } \\
\text { ers and acquisitions are the following: } \\
\text { the total cost of asset of the commercial organizations } \\
\text { participating in the merger deal exceeds } 3 \text { billion rubles; } \\
\text { their total revenue in a year before the merger deal ex- } \\
\text { ceeded } 6 \text { billion rubles; } \\
\text { one of the parties is included in the register list of the } \\
\text { companies having a share in the market of certain } \\
\text { goods in the amount of more than } 35 \% \text { or holding a } \\
\text { dominant position in the market }\end{array}$ & $\begin{array}{l}\text { Threshold values for preliminary coordination of mergers and } \\
\text { acquisitions are the following: } \\
\text { the total cost of asset of the commercial organizations partici- } \\
\text { pating in the merger deal exceeds } 7 \text { billion rubles; } \\
\text { their total revenue in a year before the merger deal exceeded } 10 \\
\text { billion rubles; } \\
\text { one of the parties is included in the register list }\end{array}$ \\
\hline $\begin{array}{l}\text { The merger deals which do not have a significant effect } \\
\text { on the competition were still under the state control of } \\
\text { economic concentration }\end{array}$ & Coordination of each M\&A deal is canceled. \\
\hline $\begin{array}{l}\text { Preliminary permission is only for the acquisition of } \\
\text { voting shares packet as a result of which the buyer can } \\
\text { control over } 20 \% \text { of the controlling share package }\end{array}$ & $\begin{array}{l}\text { Initial permission is nessesary only for for acquisition of the } \\
\text { packet of voting shares as a result of which the buyer can con- } \\
\text { trol over } 25 \% \text { of the controlling interest }\end{array}$ \\
\hline $\begin{array}{l}\text { Preliminary permission is necessary if the balance cost } \\
\text { of property constituting a subject of transaction or the } \\
\text { interconnected transactions exceeds ten percent of bal- } \\
\text { ance cost of the main production means and intangible } \\
\text { assets of economic entity making assignment or trans- } \\
\text { fer of property. } \\
\text { This barrier was not codified by low }\end{array}$ & $\begin{array}{l}\text { Preliminary permission is necessary if the balance cost of prop- } \\
\text { erty constituting a subject of transaction or the interconnected } \\
\text { transactions exceeds twenty percent of balance cost of the main } \\
\text { production means and intangible assets of economic entity } \\
\text { making assignment or transfer of property. } \\
\text { A person acquires (a group of persons) more than fifty per- } \\
\text { cent of voting shares of company founded outside the Russian } \\
\text { Federation territory }\end{array}$ \\
\hline
\end{tabular}

* FAS of 2004-2012: Report. (2013). Moscow: Federal antimonopoly service. Retrieved from: http://fas.gov.ru/about/list-of-reports/list-of-reports_30067.html (date of access: 17.07.2015). (In Russ.), pp. 18-19. The federal law «About Protection of the Competition» of 26.07.2006 No. 135-FZ (in the editorial office 156-FZ of 29.06.2015).

1. About satisfaction of petition on merger deal if this deal does not lead to restriction of competition at the market.

2. About prolongation of the term of consideration of the petition no more than for two months due to the need of its additional consideration, and also the receipt of the additional information if it is established that the merger deal declared in the petition can lead to the restriction competition. In this case, data of merger deal are posted on the official website of the Federal Antimonopoly Service, and persons, who have interested in this deal, have the right to provide data about influence on a competitive situation of this merger.

3. About prolongation of the term of consideration of the petition on merge, acquisitions, creation of commercial organization because of the need to define conditions, Once the applicants have met these conditions, FAS approve petition decides on the satisfaction of the petition, and determination of the term of accomplishment of such conditions (no more than nine months). ${ }^{1}$

\footnotetext{
1 A. N. Golomolzin (2013). Anti-monopoly regulation of energy industry: 2010-2012: Presentation. Moscow: Federal antimonopoly service. Retrieved from: http://chel.fas.gov.ru/analytic/6644 (date of access: 17.07.2016). (In Russ.)
}

Federal Antimonopoly Service coordinate a significant number of M\&A with oil and gas assets. The analysis of data FAS base on decisions in the field of economic concentration in the energy industry sphere (according to transactions with oil and gas assets) which are under authority of management on control in the field of energy industry, during the period from 2011 until the first half of the year 2015, allowed to analyze 468 merger deals. Thus, in 2013, 111 transactions were approved, in $2014-219$ deals, in the first half of $2015-121$ merger deals were approved. At the same time, the share of transactions which is issued together with the instruction constituted in $2013-1 \%$, in $2014-5 \%$, in the first half of 2015 $-2 \%$ of total transactions.

By detailed consideration of selection, it was revealed that in 2011, FAS gives information only on one decision regarding the coordination of M\&A deals concerning oil and gas assets; and in 2012 - for three transactions. At the same time, 2012 is the period of making the most significant transaction by Rosneft which acquired assets of TNK-BP. According to $\mathrm{KPMG}^{2}$ data, in 2012, in an

\footnotetext{
2 The market of M\&A in Russia in 2012 (2013). Moscow: KPMG. Retrieved from: https://www.kpmg.com/RU/ru/
} 


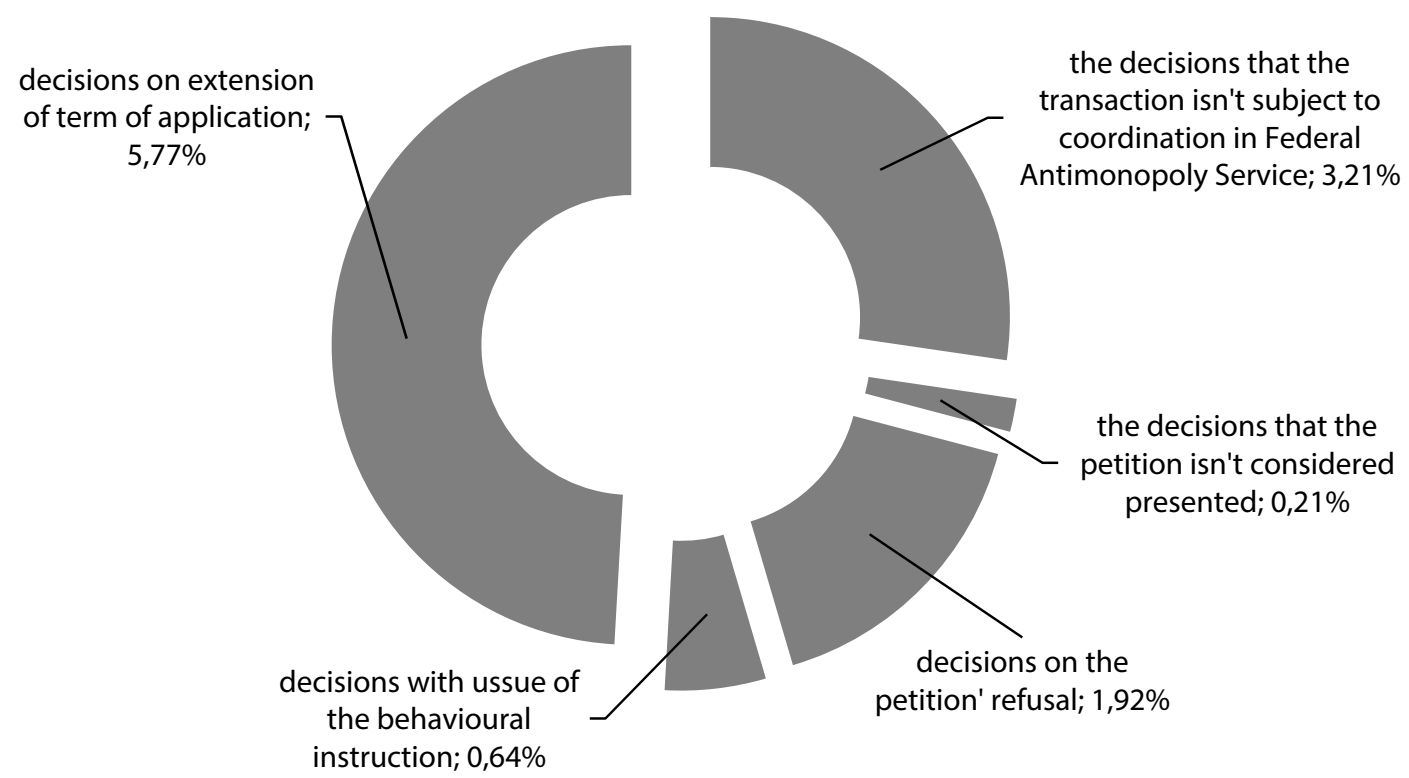

Fig. 3. Structure of decisions in the sphere of control of market concentration fuel and energy sector (oil and gas assets) during 2011-2015 (468 decisions)

oil-and-gas sector, there were made 48 transactions with assets. At the same time, the share of 10 most significant transactions (except TNK-BP assets) constituted $72,3 \%$ of the total number of transactions in the oil-and-gas sector. Even if the most M\&A deals did not need antimonopoly control, the most significant deals of 2012 concerning Gazprom, Rosneft, and Lukoil, must have relevant decision in the base of FAS. However, there are no such decisions, which shows the data of FAS are not as open and availabile. According to experts of the All-Russian Public Organization «Business Russia», the share of the FAS decisions published on the Internet constitutes no more than 5-7\% whereas the share of decisions of antimonopoly authorities of G7 countries reach $100 \%{ }^{1}$

The considered selection contained just behavioral instructions among which it was possible to select price instructions, instructions about providing non-discriminatory conditions of agreements, and also about the provision of FAS of rapid information about the change in price, releases, and structure of property. But there are no any structural instructions, which contain recommendations of FAS of the sale of a part of the business. In most cases, the instruction consisted of no more than 1-2 paragraphs. Only in three cases, the instruction size according to the transaction

IssuesAndInsights/ArticlesPublications/Documents/S_ MA_2r\%202013.pdf (date of the access 17.07.2016). (In Russ.)

${ }^{1}$ To a lump and why the 4 th anti-monopoly packet is necessary? Presentation. (2013). Moscow: All-Russian public organization «Business Russia». Retrieved from: http://naiz.org/upload/ iblock/dde/dde09907a174160edaecfe511d17996f.pdf (date of access: 17.07.2016). (In Russ.) constituted 1-2 pages, and the number of instruction points varied within five-six.

On each specific decision, the website of FAS shows the summary information about the deal with an indication of the structure of deal (the number of the acquired shares, shares in the authorized capital, amount of the acquired rights). Comparing positive decisions on deals, refusal to grant approval of petition, and decisions with instruction, we should agree with experts, there are too little information in compare with EU information (please, see data of experts ${ }^{2}$ provided in the tab. 4.)

Of course, it is difficult to find the universal tool for unmistaken correction of a competitive environment after making of a transaction. But at the same time, it is necessary to develop work in this direction. It is impossible to deny the fact that behavioral instructions of 2014 and 2015 began to contain more good corrective conditions, than it was in 2013, i. e. after acceptance of the first and second anti-monopoly packets.

It should be noted that an overwhelming part of transactions carried out in the Northwest region of the Russian Federation during 2000-2005 did harm the consumer as there was a positive reaction of the stock exchange on the acquisition of national oil and gas assets [24, pp.46-59; 25, pp. 20-37]. At the same time, the majority of the integration transactions, which are subject to coordination in 2006-2015 had no significant effect on

\footnotetext{
${ }^{2}$ To a lump and why the 4 th anti-monopoly packet is necessary? Presentation (2013). Moscow: All-Russian public organization «Business Russia». Retrieved from: http://naiz.org/upload/ iblock/dde/dde09907a174160edaecfe511d17996f.pdf (date of access: 17.07.2016). (In Russ.)
} 
Table 4

Comparative evaluation of the volumes of information presented in decisions of antimonopoly services of Russian Federation and the EU

\begin{tabular}{|l|c|c|}
\hline \multirow{2}{*}{ Types of decisions } & \multicolumn{2}{|c|}{$\begin{array}{c}\text { The volume of provided } \\
\text { information on transaction }\end{array}$} \\
\cline { 2 - 3 } & $\begin{array}{c}\text { Federal } \\
\text { Antimonopoly } \\
\text { Service of RF }\end{array}$ & $\begin{array}{c}\text { European } \\
\text { Commission }\end{array}$ \\
\hline $\begin{array}{l}\text { Permission to M\&A } \\
\text { transaction }\end{array}$ & 1 paragraph & $10-70$ pages \\
\hline $\begin{array}{l}\text { Permission to M\&A } \\
\text { transaction with } \\
\text { instructions }\end{array}$ & $1-3$ paragraphs & $30-100$ pages \\
\hline $\begin{array}{l}\text { Refusal of M\&A } \\
\text { transaction }\end{array}$ & $1-3$ paragraphs & $30-100$ pages \\
\hline $\begin{array}{l}\text { The decision on the } \\
\text { case of violation of } \\
\text { the antitrust law }\end{array}$ & Any pages & $50-100$ pages \\
\hline
\end{tabular}

the competition as the main repartition of industry assets was completed.

\section{Conclusions}

Thus, the comparison and the analysis of the quantitative and qualitative indices characterizing the Russian market of crude oil allows to come to the following conclusion: the considered goods market belongs to the market with insufficiently developed competition that is also confirmed by the level of profitability of the industry:

- The structure of the Russia oil industry has only oligopolistic nature and is characterized by the availability of the huge vertically integrated oil companies carring out activities on all segments of the oil market: oil production and oil refining, storage, wholesale, small wholesale and retail sale.

- Rosneft, Lukoil, Surgutneftegas, GazpromNeft dominate in the crude oil market and oil products market having an additional opportunity to make a full impact on the main conditions of the sale/buy of goods at the Russian oil market. The sizes of shares of other vertically integrated and multinational companies are subject to minor changes. The access of new competitors to the Russia crude oil market is complicated.

- During the period from 2004 to 2015, for the oil industry, the HHI value increased from 1251 to 1865 units. That demonstrates that the degree of the oil market concentration is as close as possible to the markets of high concentration. At the same time, the calculated value of the CR4 indices in the researched period did not exceed $80 \%$.

- The increased level of oil market concentration in does not affect the intensity of innovative activities of oil and gas companies.
- The existing level of economic concentration and companies' vertical integration availability determine the main barriers for the profit efficiency work at the market of crude oil and oil products market. The governmental restrictions to enter the oil market are the following: the need to obtain licenses, environmental constraints, the need to achieve results at the hard geological and weather conditions, the use of innovative technologies access to which is limited. Another barrier to entry the market are the limited number of refining facilities and limited capacity to use pipeline service of JSC Transneft system, as well as the dominancy of Vertically Integrated Oil Companies.

- The sellers in the researched market are the oil extraction companies; the buyers - the companies purchasing crude oils for resale or refining (the petrochemical and oil processing companies).

- Geographical boundaries of the oil market is the territory of the Russian Federation; product borders of the the wholesale markets of oil products are gasoline, diesel fuel, and aviation kerosene.

Since 2006, the the FAS antimonopoly control of oil industry allowed to create in the Russian Federation the commercial infrastructure of the oil market, promoted the development of stock exchange trading by crude oil and oil goods, and also let to register the OTC deals.

During this research, we have stated and have checked the hypothesis of the development of the mechanism of corrective conditions in the sphere of preliminary control of M\&A deals in the fuel and energy sector.

Nowadays, within the system of corrective conditions, FAS uses only official behavioral instructions. There are no structural instructions with the recommendations of antimonopoly authorities on divestment. The presented information on the website of FAS concerning decisions-making processes in the sphere of market concentration is not completed. Many of the M\&A deals, which had a direct impact on the nature of the competition in the industry are not given there. It emphasizes that FAS of the Russian Federation has the insufficient transparency of open data.

The Russian practice of M\&A deals in the oil industry shows that the majority of the deals of economic concentration subject to negotiation have no significant influence on the competition. In the list of the prohibited merges, there are merges of medium business, including those with the participation of foreign capital. While large merges, for example, purchase of assets of TNK - BP by Rosneft is approved by the Russian antimonopoly committee. FAS decided to concentrate only 
on the giant monopolists and large merges which can hold an impact on the competitiveness of the Russian oil market. Russia Federal Antimonopoly Service can protect consumers by prevention or change those mergers, which directly reduce the competitiveness of the market. The control of mergers by antimonopoly authorities is the basis for of the policy competitiveness. It is the unique area where the antimonopoly authorities can prevent the transactions capable to harm consumers.

\section{References}

1. Bain, J. S. (1962). Barriers to new competition: Their character and consequences in manufacturing industries: 2 th ed. Cambridge: Harvard University Press, 329.

2. Sherer, F. M. \& Ross, D. (1997). Structure of the industry markets. Moscow: INFRA-M Publ., 698. (In Russ.)

3. Shepherd, W. \& Shepherd, J. (2004). The Economics of Industrial Organization. USA: Waveland Press Inc., 440.

4. Avdasheva, S. B., Shastitko, A. E. \& Kalmychkova, E. N. (2007). Ekonomicheskie osnovy antimonopolnoy politiki: rossiyskaya praktika v kontekste mirovogo opyta [Economic Analysis of Russian Antitrust Policy, International Perspective]. Ekonomicheskiy zhurnal VSHE [HSE Economic Journal], 3, 381-424. (In Russ.)

5. Avdasheva, S. B. (2012). Ekonomicheskiy analiz dlya tseley primeneniya antimonopolnogo zakonodatelstva: chto, gde, kogda? [The economic analysis for the purposes of application of the antitrust law: what, where, when?]. Konkurentnoye pravo [Competition Law], 1, 5-11. (In Russ.)

6. Sushkevich, A. G., Avdasheva, S. B. \& Markin, M. E. (2013). Sotsiologicheskie metody v otsenke effektov gosudarstvennoy politiki (na primere antimonopolnogo kontrolya sliyaniy) [Using sociological methods to access the im pact of the pu blic policy (a case of the merger notification)]. Sovremennaya konkurentsiya [Modern competition], 2(38), 3-18. (In Russ.)

7. Rozanova, N. M. (2006). Politika podderzhki konkurentsii i promyshlennaya politika v zarubezhnykh stranakh [Policy of the support of the competition and industrial policy in foreign countries]. Ekonomicheskiy vestnik Rostovskogo gosudarstvennogo universiteta [Terra Economicus], 1(4), 32-47. (In Russ.)

8. Chernova, E. G. (2010). Sovremennyye formy i metody integratsii khozyaystvennykh obrazovaniy $v$ usloviyakh globalizatsii: monografiya [Modern forms and methods of integration economic educations in the conditions of globalization: monograph]. Saint Petersburg: St. Petersburg State University Publ., 280. (In Russ.)

9. Chernova, E. G. \& Pakhomova, N. V. (2011). Rossiyskiy rynok sliyaniy i pogloshcheniy: napravleniya i perspektivy razvitiya: kollektivnaya monografiya [Russian market of M\&A: directions and prospects of development: collective monograph]. In: E. G. Chernova, N. V. Pakhomova (Eds). Saint Petersburg: St. Petersburg State University Publ., 256. (In Russ.)

10. Pakhomova, N. V. \& Richter, K. K. (2009). Ekonomika otraslevykh rynkov i politika gosudarstva [Economy of the industry markets and State policy]. Moscow: Economika Publ., 815. (In Russ.)

11. Pakhomova, N. V. (2008). Sovremennaya konkurentnaya politika: teoreticheskiy analiz i opyt realizatsii (na primere ES i Rossii) [Present Competitive Policy: Theoretical Analysis and Practical Experience (Cases of the European Union and Russia)]. Vestnik Sankt-Peterburgskogo gosudarstvennogo universiteta [Vestnik of Saint Petersburg State University], 2, 3-24. (Series 5 Economics). (In Russ.)

12. Pakhomova, N. V. \& Nekrasova, E. A. (2013). Konkurentnaya politika i razvitie antimonopolnogo regulirovaniya v Rossii [Competition Policy and Antitrust Regulation Development in Russia]. Vestnik Sankt-Peterburgskogo gosudarstvennogo universiteta [Vestnik of Saint Petersburg State University], 3, 25-36. (Series 5 Economics). (In Russ.)

13. Nekrasova, E. A. (2013). Sdelki sliyaniy i pogloshcheniy v konkurentnoy politike Rossii: aspekty regulirovaniya [M\&A deals in competition policy of Russia: aspects of regulation]. Problemy sovremennoy ekonomiki [Problems of modern economy]. Saint Petersburg: Research and Production Company Rost Publ., 2(46), 58-61. (In Russ.)

14. Duso, T., Gugler, K. \& Szücs, F. (2013). An Empirical Assessment of the 2004 EU Merger Policy. Economic Journal, 123(572), 596-619.

15. Nocke, V. \& Whinston, M. (2010). Sequential merger review. Journal of Political Economy, 118(6), $1200-1251$.

16. Nocke, V. \& Whinston, M. (2010). Dynamic Merger Review. The Journal of Political Economy, 118(6), $1201-1251$.

17. Nocke, V. \& Whinston, M. (2013). Merger policy with merger choice. American Economic Review, 103(2), 10031033.

18. Thomasin, S. (2013). Close Competitors in Merger Review. Journal of European competition law \& practice, 4(5), 391-401.

19. Cloughert, J. \& Seldeslachts, J. (2013). The Deterrence Effects of US Merger Policy Instruments. Journal of Law, Economics, and Organization, 29(5), 1114-1144.

20. Burguet, R. \& Caminal, R. (2015). Bargaining failures and merger policy. International Economic Review, 56(3), 1019-1041.

21. Budzinski, O. \& Ruhmer, I. (2009). Merger simulation in competition policy: A survey. Journal of Competition Law and Economics, 6(2), 277-319.

22. Mason, R. \& Weeds, H. (2013). Merger policy, entry, and entrepreneurship. European Economic Review, 57, $23-38$.

23. Breinlich, H., Nocke, V. \& Schutz, N. (2016). International aspects of merger policy: A survey. International Journal of Industrial Organization. Retrieved from: http://dx.doi.org/10.1016/j.ijindorg.2016.05.001 (date of the access: 07.07.2017). 
24. Razmanova, S. V. (2010). Issledovanie effektivnosti integratsionnykh protsessov v neftegazovoy otrasli [Study of efficiency of integration processes in oil and gas branch]. Finansy $i$ kredit [Finance and credit], 23(407), 46-59. (In Russ.)

25. Razmanova, S. V. (2016). Analiz effektivnosti transnatsionalnykh sdelok sliyaniy i pogloshcheniy na razvivayushchikhsya rynkakh kapitala [Analysis of the effectiveness of transnational mergers and acquisitions in emerging capital markets]. Vestnik Sankt-Peterburgskogo gosudarstvennogo universiteta [Vestnik of Saint Petersburg State University], 3, $20-37$. (Series 5 Economics). doi: 10.21638/11701/spbu05.2016.302. (In Russ.)

\section{Authors}

Elena Grigoryevna Chernova - Doctor of Economics, Professor, Vice Rector for Economy, Saint-Petersburg State University (Russia, 7/9, Universitetskaya Emb., St. Petersburg, 199034, Russian Federation; e-mail: e.chernova@spbu.ru).

Svetlana Valerievna Razmanova - PhD in Economics, Associate Professor, Head of Laboratory, Branch Office of LLC Gazprom VNIIGAZ in Ukhta; Scopus Author ID: 56117404000, ORCID: 0000-0002-3865-8508, Researcher ID: B-14422014; (1a, Sevastopolskaya St., Ukhta, Republicc of Komi, 169300, Russian Federation; e-mail: s.razmanova@sng.vniigaz. gazprom.ru). 